\title{
Efektivitas Pupuk Organik Cair Fermentasi Extrak Daun LamtoroGung Terhadap Pertumbuhan Produksi Jagung Lokal Mandar
}

\section{Effectiveness of Liquid Organic Fertilizer Fermentation GungLeucaena Leaf Extract on Growth and Production of Maize Local Mandar}

\author{
Muh Rifky Aulia, Makmur M* \\ Jurusan Agroteknologi, FakultasIlmu Pertanian, Universitas AlAsyariah Mandar, \\ Jl. BudiUtomo No 2, Manding, PolewaliMandar, Sulawesi Barat 91311, Indonesia \\ *Email: almakmur888@gmail.com
}

\begin{abstract}
Corn is a strategic food commodity and has economicvalue and has the opportunity to be developed because of its position as the main source of carbohydrates and proteinafter rice. At present the productivity of corn plants in Indonesia only reaches 4.1 tons / ha at the farm level, the productivity is still low compared to the optimum productivity that can be achieved around 12 tons / ha. Thepurpose of this study was to determine the effect of administering various doses of liquid organic fertilizer (POC) fermented from lamtoro leaf extracts on corn plants. Themethod used was a randomized blockdesign (RBD), namely the provision of POC from the fermentation of lamtoro leaf extract consisting of 5 levels, namely: Control, $15 \mathrm{ml} /$ liter ofwater, $20 \mathrm{ml} /$ liter of water, $25 \mathrm{ml} /$ liter of water and $30 \mathrm{ml} /$ liter water. Located in the Experimental Garden of the Faculty of Agriculture, Unasman, Madatte Village, Polewali District, Polewali Mandar Regency from January to April 2020. The results of this study show that the average value of all parameters is greater than NP. LSD level of 5\% so that conclusions can be drawn namely: giving a dose of $30 \mathrm{ml} /$ liter of water gives the best effect and significantly different from other treatments on plant height parameters age 21, 28, and 56 DAP, number of leaves aged 21, 28, and 56 DAP , age of male flowering, cob length, cob weight, weight 100 seeds, and stem dry weight.
\end{abstract}

Keywords: lamtoro leaf, corn, production, productivity, POC

\begin{abstract}
Abstrak
Jagung merupukan tanaman panganyang bernilai ekonomis tinggi dan juga mempunyaipeluang untuk dikembangkan karena jagung saat ini merupakan sumber utamakarbohidrat dan protein setelahberas. Produktivitas tanaman jagung di Indonesia hanya mencapai 4,1 ton/ha di tingkat petani, produktifitas tersebut masih rendah dibandingkan dengan produktifitas optimum yang bisa dicapai sekitar 12 ton/ha. Penelitian ini bertujuan mengetahui pengaruhpemberian berbagai dosis pupukorganik cair (POC) hasilfermentasi extrak daun lamtoro pada tanaman Jagung. Metode yang di gunakan adalah rancangan acak kelompok (RAK) yaitu pemberian POC hasil fermentasi extrak daun lamtoro yang tediri dari 5 taraf yaitu : Kontrol, 15ml/literair, 20ml/literair, 25ml/literair dan 30ml/literair. Berlokasi di Kebun Percobaan Fakultas Ilmu Pertanian Unasman, Kelurahan Madatte, Kecamatan Polewali, Kabupaten Polewali Mandar dari bulan Januari sampai April 2020. Hasil penelitian ini menujukkan bahwa nilai rata-rata semua peubahlebih besar dari NP. BNT taraf $5 \%$ sehingga dapat diambil kesimpulan yaitu: pemberian dosis $30 \mathrm{ml} /$ liter air memberikan pengaruh terbaik dan berbeda sagat nyata dengan perlakuan lain pada peubahtinggi tanaman umur21,28,dan 56HST, jumlah daun 21,28, dan 56HST, umur berbunga jantan, PanjangTongkol, BobotTongkol, Bobot100 Biji, dan BobotKering Batang.
\end{abstract}

Kata Kunci: daun lamtoro, jagung, produksi, produktifitas, POC

\section{Pendahuluan}

Jagung (Zea mays L.) urutan ketiga didunia sebagai tanaman serealiapenting setelah gandum danpadi. Di Indonesia jagung saat ini menjadi komoditas pangan favorit kedua setelah beras oleh msayarakt untuk di kembangkan, selain bernilai ekonomis yang tinggi, jagung jugasebagai sumber utama karbohidrat danprotein setelahberas. Bahkan Jagung berperan dalam hal peningkatan perekonomian nasional karena dalam subsektor tanamanpangan jagung penyumbang terbesarkedua setelah padi (Murni, et al., 2014). Badan Pusat Statistik (2018) mencatat bahwa produksijagung dalam 5tahun terakhir masih berfluktuatif, rata-rata $12,49 \%$ pertahunnya. Diprediksi tahun 2020 produksi jagungdiperkirakan mencapai 30juta ton, ini didukung olehdata luas panen pertahun yang rata-rata meningkat $11,06 \%$, dan produktivitas rata-rata meningkat $1,42 \%$. Akan tetapi produktivitas jagung Indonesia lebih rendah dibandingkan dengan Negara negara kawasan. Padahal, Indonesia memiliki lahan lebih luas di antara negara lainnya. Saat ini produktivitastanaman jagung di Indonesia hanyamencapai 4,1 ton/ha di tingkat petani, produktifitas tersebut masih rendah dibandingkan dengan produktifitas optimum yang bisa dicapai sekitar 12 ton/ha, 
hal ini mengindikasikan bahwa kita masih jauh dari target pemerintah dengan swasembada pangan khususnya jagung. Salah satu faktor rendahnya produktifitas tanamanjagung dikarenakan lahan pertanaman yang kering oleh rendahnya curahhujan (St. Subaedah et al., 2018), dan juga disebabkan oleh teknik budidaya yang kurang tepat diantaranya adalah pemupukan dan jenis pupuk yang digunakan. Bahkan penurunan hasil jagung ditemukan lebih tinggi dari gandum yaitu sekitar 39,3\% : 20,6\% (Daryanto et al., 2016).

Selama ini, petani melakukan pemupukan sangat mengandalkan pupuk anorganik (Nasaruddin dan Rosmawati, 2011). Penggunaan pupuk kimia secara berlebihan menyebabkan sejumlah masalah terhadap kerusakan lingkungan dan apabila pupuk kimia ini digunakan dalam jangka waktu yang panjang akan menyebabkan matinya mikroorganisme yang ada di dalam tanah dan hal ini tentu saja mempengaruhi tingkat kesuburan tanah (Wahyu Arif Sudarsono et al., 2013).

Upaya peningkatan produksi dan produktivitas tanaman jagung melalui pengurangan penggunaan pupuk kimia harus terus dilakukan yaitu salah satunya dengan penggunaan pupuk organik yang bersumber dari bagian-bagian tanaman. Salahsatu pupukorganik yang bisa dimanfaatkan adalah pupuk organik dalam bentuk cair dan dari extrakdaun lamtoro, pupuk ini memiliki unsur hara yang cukuptinggi, terutama unsur Nnya, selain itu pupuk ini juga mudah teruruari/terdekomposisi sehinggapenyediaan haranya dalam tanah lebihcepat.

Pupuk daun lamtoro inimengandung nutrisi utama yaitu: $\mathrm{N}$ nya $3,84 \%$, P nya $0,2 \%$, K nya $2,06 \%$, Ca nya $1,31 \%$, dan Mg nya $0,33 \%$ (Putri Wening Ratrinia et al., 2014). Salah satu kelebihan Pupuk organik cair ini adalah lebih efisien, dikarenakan pupuk organik cair aplikasinya disiramkan dan disemprotkan langsung ke tanaman sehingga harayang terkandung dalam pupuk cair inidapat langsung diserap olehtanaman. Berdasarkan hal tersebut diatas maka penelitian ini dilakukan dengan memfokuskan penggunaan bagian dari tanaman lamtro yaitu melalui fermentasi dari extrak daun lamtoro sebagai pupukorganik cair (POC) yangdiharapakan bisa menjadikan produksi dan produktifitas tanaman jagung meningkat.

\section{Metode Penelitian}

Penelitian dilaksanakan dikebun percobaan FIP Unasman, Kelurahan Madatte, Kecamatan Polewali, Kabupaten Polewali Mandar dari bulan Januari - Mei 2020.

Bahan yang digunakan dalampenelitian ini adalahbenih, daun lamtoro, gula merah, dan air cucian beras. sedangkan alat yang digunakan adalah alat tulis menulis,cangkul, timbangan digital,ember, plastik, meteran,selang air, gembor,kamera, sprayer dan tali rafia.

Metode yang di gunakan adalah rancangan acak kelompok (RAK) satu faktor yaitu POC extrak daun lamtoro yang tediri dari 5 taraf perlakuan antara lain:

1. L0 : Tanpa extrak daun lamtoro (Kontrol)

2. L1: POC extrak daun lamtoro $15 \mathrm{ml} /$ literair

3. L2: POC extrak daun lamtoro $20 \mathrm{ml} /$ literair

4. L3: POC extrak daun lamtoro $25 \mathrm{ml} /$ literair

5. L4: POC extrak daun lamtoro $30 \mathrm{ml} /$ literair
Setiap perlakuan diulang 4 kali sehinga terdapat 20unit perlakuan. Setiap unit perlakuan terdapat 15tanaman sehingga jumlahtanaman yang di butuhkan seluruhnya yaitu 300 tanaman.

Tahapan pelakasanaan peneltan sebagai berikut :

Pembuatan POC extrak daunlamtoro gung (konsentrasi $1 \mathrm{~kg}$ daun lamtoro : $2 \mathrm{~L}$ air beras) dan ditambahkan $200 \mathrm{~g}$ gula merah. Cara pembuatan yaitu daunlamtoro dipotongpotong lalu ditumbuk/dihaluskan, lalu dimasukkan kedalam jarigen, masukkan juga gulamerah yang sudahdiiris halus, menyusul air beras kedalam jarigen, diaduk sampai rata selama beberapa menit, lalu di fermentasikan selama 21 hari.

Varietas jagung yang digunakan adalah jagung hibrida P36. Persiapan lahan dilakukan dengan cara mengolah tanah secara merata, selanjutnya dibuat petak atauulangan percobaan dengan ukuran $3 \times 3 \mathrm{~m}$, djarak antar petakan $50 \mathrm{~cm}$. Penanaman dilakukan dengan jarak tanam $70 \mathrm{~cm} \times 20 \mathrm{~cm}$. Benih ditanam 2biji pada masing-masing lubang tanam, lalu ditutupi dengan tanah.

Pemberian POC extrak daun lamtoro diberikan setiap 2 minggu sekali dengan cara mencampurkan pupuk tersebut dengan satu liter air kemudian diaduk lalu disemprotkan ke tanaman menggunakan sprayer kebagian daun sampai permukaan tanah, dosis sesuai perlakuan yaitu: : Tanpa pupuk extrak daun lamtoro (Kontrol) (L0), POC daun lamtoro $15 \mathrm{ml} /$ liter air (L1), POC daun lamtoro $20 \mathrm{ml} / \mathrm{liter}$ air (L2), POC daun lamtoro $25 \mathrm{ml} / \mathrm{liter}$ air (L3) dan POC daun lamtoro $30 \mathrm{ml} /$ liter air (L4)

Pemeliharaan meliputi kegiatan penyiraman, penyulaman, penyiangan, pembumbunan, pengendalian OPT (Organisme pengganggu tanaman), dan pembumbunan. Penyiraman dilakukan 2 kali sehari secara teratur sesuai dengan keperluan tanaman, penyulaman jugadilakukan dengan menanam benihjagung kembali kelubang tanam yang tidaktumbuh, pembumbunan dilakukan dengan menaikan tanah kedekat perakaran agar tanaman tumbuh dengan kuat dan optimal, Pengendalian OPT tergantung serangan hama dan penyakit.

\section{Hasil dan Pembahasan}

\subsection{Pengaruh TinggiTanaman Umur14, 28 dan 56 HST}

Berdasarkan olah data dan analisis ragam yang telah dilakukan menunjukan bahwapemberian POC extrak daunlamtoro berpengaruh baik pada peubah tinggitanaman umur14, 28 dan56 HST. Hasil uji BNT taraf5\% (lihat Tabel 1), memperlihtkan bahwa POC extrak daun lamtoro dosis 30ml/liter air(L4) berpengaruh baik dibanding dengan perlakuan lainnya pada umur 14 HST dengan nilai rata-rata tertinggi yaitu 31.67, sedangkan pada umur 28 HST aplikasi pupuk POC daunlamtoro dosis 30ml/literair (L4) juga berpengaruhbaik dibanding dengan perlakuanlainnya dengan nilai rata-rata tertinggi yaiu 78.38 , tetapi tidak berbeda dengan dosis $25 \mathrm{ml} /$ liter air (L3). Selanjutnya pada umur 56 HST pemberian POC extrak daun lamtoro dosis 30ml/literair (L4) juga berpengaruh baik dibanding dari pada perlakuanlainnya dengan nilai rata-ratatertinggi yaitu 
161.44, tetapi tidak berbeda dosis 25ml/literair (L3). Adanyapengaruh POC extrak daunlamtoro pada umur14, 28dan 56HST tersebut diduga bahwa dengan konsentrasi 30ml/literair ini mampu mensuplaikebutuhan unsur hara terutama unsur nitrogen yang terdapatpada POC ini menjadikan adanya respon yang baik pada tanamanjagung, kemudian unsur nitrogen tersebut dapat langsn diserap oleh tanaman melalui stomatadaun. Selain itu pupuk ini mengandung unsur-unsur hara makro yangsangat dibutuhkn oleh tanaman khusunya tanaman jagung, unsur tersebut berupa unsur nitrogen, posfor, dan kalium. Ketiga unsur ini sangatdibutuhkan tanaman untuk prosesfisiologi dan metabolismenya sehingga ketika proses ini berjalan akan memicu pertumbuhandan tinggi tanaman jagung. Proses metabolism tanaman akan berjalan dengan baik apabila semakin banyak konsentrasi dari POC daun lamtoro yang diberikan, asumsi ini mengatakan kondisi tanaman dalam keadaan baik dan tidak terganggu metabolismenya(Tiara Septirosya et al., 2019). Menurut Jurhana (2017) dari ketiga unsur hara esensial yang sangat dibutuhkan tanamn, unsur hara nitrogenlah yang mampu mendorong dan mempercepat pertumbuhan dan pertambahan tinggi tanaman. Sintesa asam-asamamino dan proteinsangat berperan pada ketersediaan unsur nitrogen pada tanamanterutama pada titik-titik tumbuh tanaman, hal ini mengakibatkan proses pertumbuhan tanamanseperti pembelahan sel dan perpanjangan sel juga ikut meningkat yang pada prosesnya meningkatkan tinggi tanaman. Penelitian Dedi Nursyamsi (2009), respon tanaman terhadap bahan organik pada tanaman jagung ditandai dengan adanya asamoksalat yang dikeluarkan oleh akar jagung, asam ini merupakan yang paling dominanyang tergolong asam organik diantara asam -asam lainnya yangberpengaruh pada pertumbuhan vegetative tanaman jangung.

\subsection{Pengaruh Banyaknya Daun Umur 14, 28 dan 56 HST}

Berdasarkan olah data dan analisis ragam yang telah dilakukan memperlihatkan bahwaaplikasi POC extrak daun lamtoro berpengaruh baik pada peubah banyaknya daun umur14, 28 dan 56HST. Hasil UJBD taraf 5\% (lihat Tabel 2), memperlihatkan aplikasi POC daun lamtoro dosis 30ml/literair (L4) berpengaruh baikdibanding dengan perlakuanlainnya pada umur 14HST dengan nilai rataan tertinggi yaitu 4.00(helai), lalu umur28 HST aplikasi POC extrak daun lamtoro $30 \mathrm{ml} /$ literair (L4) juga berpengaruh baik dibanding dengan perlakuanlainnya dengan nilai rataan tertinggi yaiu 7.75(helai), tetapi tidak berbeda dengan dosis $25 \mathrm{ml} /$ liter air (L3). Selanjutnya pada umur 56HST aplikasi POC extrak daunlamtoro dosis $30 \mathrm{ml} / \mathrm{liter}$ air (L4) juga berpengaruh baik dibanding dengan perlakuan lainnya dengan nilai rataan tertinggi yaitu 16.00(helai). Hal tersebut diduga karena degan pemberian POC yang diadalamnya terdapat unsur nitrogen, hal ini ini diasumsikan bahwa kandungan unsurnitrogen ini yang diberikan pada tanaman dapat mempercepat proses fotosintesisnya sehingga pembentukanorgan daunpun menjadi lebihcepat. Selain unsur nitrogen, POC daun lamtoro juga mengandung unsur hara posfor dan unsur kalium yang sangat berguna untuk mencukupi kebutuan bagi tanaman. Unsur nitrogen sendiri dapat merangsang pertumbuhan batangdan daun, kemudian unsur hara fosfor (P) berfungsi untuk merangsang pertumbuhanakar, sedangkan Kalium sebagai penguat tubuhtanaman agar daun, bunga dan buah tidakmudah gugur (Sulham dan Retno Wulandari, 2019). Selanjutnya pada perlakuan L0 (control) mengalami hambatan pada proses pebentukan daun, ini dikarenakan tidak terpenuhinya kebutuhan hara terutama $\mathrm{N}$ yang berperan dalam pertumbuhan vegetative tanaman. Pada prosesnya ketersediaan unsur nitrogen dan posfor sangat dipengeruhi oleh kedua unsur ini yang berkaitan proses biokimia yang terjadi dalam tubuhtanaman diantaranya dalam pembentukan sel-sel baru, serta penyusunsenyawa organik dalam tanaman seperti asam amino, asam nukleat, klorofil, ADP danATP. Kedua unsur inilah yang sangat berperan dalam menyusun ini.

\subsection{Pengaruh Panjang Tongkol, BobotTongkol, Bobot 100 Biji, dan BobotKering Batang}

Hasil UJBNT taraf 5\% (lihat Tabel 3), memperlihatkan bahwaaplikasi POC extrak daun lamtoro 30ml/literair (L4) berpengaruhbaik dibanding dengan perlakuanlainnya pada panjang tongol dengan nilai rataan tertinggi yaitu $17.18 \mathrm{~cm}$, sedangkan pada bobottongkol aplikasi POC extrak daun lamtoro 30ml/liter air (L4) juga berpengaruh baik dibanding denganperlakuan lainnya dengan nilai rata-rata tertinggi yaiu 193.35gram. Selanjutnya pada bobot 100biji aplikasi POC extrak daun lamtoro 30ml/literair (L4) berpengaruh baik dibanding dengan lainnya dengan nilai rataan tertinggi yaitu 29.93gram, tetapi tidak berbeda dengan dosis 25ml/literair (L3). Lalu pada bobotkering batang aplikasi POCextrak daun lamtoro dosis 30ml/literair (L4) berpengaruh baik dibanding perlakuanlainnya dengan rataan tertinggi yaitu 280.50gram, tetapi tidak berbeda dengan dosis 25ml/literair (L3).

Adanya pengaruhpupuk organik cair extrak daun lamtora pada panjang tongkol tersebut diduga karena unsurhara posfor dan unsurkalium yang dikandung oleh POC ini diasumsikan sudah dapat memenuhi kebutuhan tanaman jagung, sehingga konsentrasi POC daun lamtoro yang tinggi sangat perlu dilakukan untuk dapat menunjang perkembangan tongkol pada tanaman. POC ini memberikan keseimbangan antara unsur-unsur hara lainnya yaitu unsur haramakro dan mikropada tanaman. ketersediaan unsur haraesensial sangat berpengaruh dalam hal memberikan hasil yangmaksimal. Hasil penelitian Kurniati et al., (2017) menyatakan bahwasemakin tinggi konsentrasi/dosis daun lamtoro maka akansemakin tinggi pula kandungan posfordan kaliumnya. Pada peranannya posfor sangat dibutuhkan saat tanaman jagung mulaipembentukan tongkol, mekanismenya denganmengaktifkan pengisian tongkol dan mempercepat pemasakanbiji., sedangkan unsurkalium sendiri dibutuhkan pada saat tanaman sudah mulai keluar malainya. Lalu pada bobot tongkol, bobot100 biji dan bobot kering batang pemberian POC ini berpengaruh baik diduga bahwa dengansemakin tingginya konsentrasi POC yang diberikan maka ketersediaan unsurunsur makro brupa nitrogen, posfor dan kalium yang dibutuhkan tanaman diasumsikan sudah terpenuhi sehingga pada prosesnya dalambatas tertentu saat tanaman memasuki fase generatifnya dengan mulai terbentuknyabunga dapat memacu pada penambahan bobot tongkol dan pembentukan baris biji pertongkol. Selain itu keberadaan unsur-unsur ini 
membuat metabolisme berjalanbaik dan hasilnya kemudian ditranslokasikan untuk penambahan bobot tongkol serta pembentukan baris biji pada tongkol jagung manis, sejalan denganpenelitian Eni Maftu'ah et al. (2013) kandungan BO dalam tanah dapat mempengaruhi pertumbuhan dan serapan hara NPK dalam tanah. Pada prinsipnya pertumbuhan danproduksi serta mutu hasil jagung sangat dipengaruhi oleh duafaktor, yaitu faktor lingkungan (kesuburan tanah) dan faktor genetiknya (Jurhana, 2017; Mukhofifatul Ainiya et al., 2019).

\section{Kesimpulan}

Hasil penelitian yang dilakukan dapat disimpulkan bahwa aplikasi POCextrak daun lamtoro dengan dosis $30 \mathrm{ml} /$ literair berpengaruh baik pada peubah tinggi tanaman umur14, 28dan 56 HST, banyaknya daun umur 4, 28 an 56 HST, panjang tongkol, bobot tongkol, berat100 biji, dan bobotkering batang.

\section{Ucapan Terimakasih}

Ucapan terimakasih disampaikan kepada LLDIKTI Wilayah 9, Universitas Al Ayariah Mandar, LPPM Universitas Al Ayariah Mandar, lembaga atau pihak lainya atas bantuannya dalam pelaksanaan penelitian. Terima kasih juga disampaikan kepada para teknisi lapangan Kebun Percobaan FIP, serta semua yang ikut membantu atas dedikasi dan kerjasama selama penelitian berlangsung.

\section{Daftar Pustaka}

Badan Pusat Statistik. 2018. Rata rata produksi dan produktifitas jagung. http://www.bps.go.id. [18 September 2019].

Daryanto, S., L. Wang, P.A. Jacinthe. 2016. Global synthesis of drought effects on maize and wheat production. PLOS One 11, e0156362.

Dedi, N. 2009. Pengaruh kalium dan varietas jagung terhadap eksudat asam organik dari akar, serapan $\mathrm{N}, \mathrm{P}$, dan $\mathrm{K}$ tanaman dan produksi brangkasan jagung (Zea mays L.). J. Agron. Indonesia 37 (2):107114.

Eni, M., A. Maas, A. Syukur, B.H. Purwanto. 2013. Efektivitas amelioran pada lahan gambut terdegradasi untuk meningkatkan pertumbuhan dan serapan NPK tanaman jagung Manis (Zea mays L. var. saccharata). J. Agron. Indonesia 41 (1):16-23.

Jurhana, UM., M. Ichwan. 2017. Pertumbuhan dan Hasil tanaman jagung Manis (Zea mays L. saccharata Sturt) pada berbagai dosis pupuk organik. e-J. Agrotekbis 5 (3):324-328.

Kurniati, E., A.D. Shirajjudin, Imani E.S. 2017. Pengaruh penambahan bioenzim dan daun lamtoro (L. Leucocephala) terhadap kandungan unsur hara makro $(\mathrm{C}, \mathrm{N}, \mathrm{P}$ dan $\mathrm{K}$ ) pada pupuk organik cair (POC) lindi (Leachate). Jurnal Sumberdaya Alam dan Lingkungan. 4 (1):20-26.

Laconi, E.B., T. Widiyastuti. 2010. Kandungan xantofil daun lamtoro (Leucaena leucocephala) hasil detoksifikasi mimosin secara fisik dan kimia. Med Pet. 33(1):50-54.

Mukhofifatul, A., M. Fadil, R. Despita. 2019. Peningkatan pertumbuhan dan hasil jagung manis dengan pemanfaatan Trichokompos dan POC daun lamtoro. Jurnal Agrotech Res J 3(2):69-74
Murni , A.M dan R.W. Arief. 2014. Teknologi Budidaya Jagung. Balai Besar Pengkajian dan Pengembangan Pertanian. Bogor. $17 \mathrm{Hlm}$

Nasaruddin dan Rosmawati. 2011. Pengaruh pupuk organik cair (POC) hasil fermentasi daun gamal, batang pisang dan sabut kelapa terhadap pertumbuhan bibit kakao. Jurnal Agrisistem. 7 (1):29-37.

Putri, W.R., W.F. Maruf, E.N. Dewi. 2014. Pengaruh penggunaan bioaktivator EM4 dan penambahan daun lamtoro (Leucaena leucocephala) terhadap spesifikasi pupuk organik cair rumput laut (Eucheuma spinosum). Jurnal Pengolahan dan Bioteknologi Hasil Perikanan. 3 (3):82-87.

Subaedah, St., N. Sudirman, Saida. 2018. Penampilan pertumbuhan dan hasil beberapa genotipe jagung calon hibrida umur genjah di lahan kering. J. Agron. Indonesia. 46 (2):169-174.

Sulham, R. Wulandari. 2019. Pengaruh kompos daun lamtoro (Leucaena leucocephala) terhadap pertumbuhan semai cempaka kuning (Michelia champaca L). Jurnal Warta Rimba 7 (3).

Siboro, E.S., E. Surya, N. Herlina. 2013. Pembuatan pupuk cair dan biogas dari campuran limbah sayuran. Jurnal Teknik Kimia USU 2(3):4043.

Tiara, S., R.H. Putri, T. Aulawi. 2019. Aplikasi pupuk organik cair lamtoro pada pertumbuhan dan hasil tanaman tomat. jurnal AGROSCRIPT $1(1): 1-8$.

Wahyu, A.S., M. Melati, S.A. Aziz. Pertumbuhan, serapan hara dan hasil kedelai organik melalui aplikasi pupuk kandang sapi. J. Agron. Indonesia 41 (3):202-208. 
TABEL

Tabel 1. Hasil Rataan TinggiTanaman Jagung Umur14, 28 dan 56 HST

\begin{tabular}{lccc}
\hline Perlakuan & \multicolumn{3}{c}{ Rataan TinggiTanaman $(\mathbf{c m})$} \\
\cline { 2 - 3 } & $\mathbf{1 4 H S T}$ & $\mathbf{2 8 H S T}$ & $\mathbf{5 6 H S T}$ \\
\hline L0 : (control) & $28.58^{\mathrm{a}}$ & $57.04^{\mathrm{a}}$ & $136.39^{\mathrm{a}}$ \\
L1: $15 \mathrm{ml} /$ liter air & $28.59^{\mathrm{a}}$ & $62.96^{\mathrm{a}}$ & $139.37^{\mathrm{a}}$ \\
L2: $20 \mathrm{ml} /$ liter air & $28.75^{\mathrm{a}}$ & $65.43^{\mathrm{a}}$ & $140.20^{\mathrm{a}}$ \\
L3: $25 \mathrm{ml} /$ liter air & $28.25^{\mathrm{a}}$ & $71.17^{\mathrm{b}}$ & $155.16^{\mathrm{b}}$ \\
L4: $30 \mathrm{ml} /$ liter air & $31.67^{\mathrm{b}}$ & $78.38^{\mathrm{c}}$ & $161.44^{\mathrm{c}}$ \\
\hline NP. UJBNT taraf 5\% & 2.04 & 3.86 & 5.54 \\
\hline
\end{tabular}

Keterangan : Angka yang diikuti oleh hurufyang tidaksama berarti berbeda sangat nyatapada UJBNT taraf 5\%.

Tabel 2. Hasil Rataan Banyaknya Daun Jagung Umur14, 28 dan 56 HST

\begin{tabular}{lccc}
\hline Perlakuan & \multicolumn{3}{c}{ Rataan Banyaknya Daun (Helai) } \\
\cline { 2 - 4 } & 14HST & 28HST & 56HST \\
\hline L0 : (control) & $2.50^{\mathrm{a}}$ & $5.75^{\mathrm{a}}$ & $11.50^{\mathrm{a}}$ \\
L1: $15 \mathrm{ml} /$ liter air & $2.75^{\mathrm{a}}$ & $6.25^{\mathrm{a}}$ & $13.50^{\mathrm{a}}$ \\
L2: $20 \mathrm{ml} /$ liter air & $3.75^{\mathrm{a}}$ & $6.75^{\mathrm{a}}$ & $13.25^{\mathrm{a}}$ \\
L3: $25 \mathrm{ml} /$ liter air & $3.75^{\mathrm{a}}$ & $7.25^{\mathrm{b}}$ & $14.25^{\mathrm{a}}$ \\
L4: $30 \mathrm{ml} /$ liter air & $4.00^{\mathrm{b}}$ & $7.75^{\mathrm{c}}$ & $16.00^{\mathrm{b}}$ \\
\hline NP. UJBNT taraf $\mathbf{5 \%}$ & 0.80 & 1.13 & 2.29
\end{tabular}

Keterangan : Angkayang diikuti oleh hurufyang tidaksama berarti berbeda sangat nyatapada UJBNT taraf 5\%.

Tabel 3. Hasil Rataan Panjang Tongkol, BobotTongkol, Bobot100 Biji, dan BobotKering Batang

\begin{tabular}{|c|c|c|c|c|}
\hline \multirow[t]{2}{*}{$\begin{array}{l}\text { Perlakuan } \\
\text { P0C Daun Lamtoro }\end{array}$} & \multicolumn{4}{|c|}{$\begin{array}{l}\text { Rataan PanjangTongkol, BobobtTongkol, Bobot100 Biji, dan Bobot } \\
\text { Kering Batang }\end{array}$} \\
\hline & $\begin{array}{c}\text { Panjang Tongol } \\
(\mathrm{cm})\end{array}$ & $\begin{array}{c}\text { Bobot } \\
\text { Tongkol } \\
\text { (g) }\end{array}$ & $\begin{array}{c}\text { Bobot } 100 \text { Biji } \\
(\mathrm{g})\end{array}$ & $\begin{array}{c}\text { Bobot Kering Batang } \\
(\mathrm{g})\end{array}$ \\
\hline L0 : (control) & $12.85^{\mathrm{a}}$ & $150.06^{\mathrm{a}}$ & $26.08^{\mathrm{a}}$ & $162.25^{\mathrm{a}}$ \\
\hline $\mathrm{L} 1: 15 \mathrm{ml} / \mathrm{liter}$ air & $15.05^{\mathrm{a}}$ & $169.04^{\mathrm{a}}$ & $26.53^{\mathrm{a}}$ & $171.75^{\mathrm{a}}$ \\
\hline L2: 20 ml/liter air & $14.98^{\mathrm{a}}$ & $172.39^{\mathrm{a}}$ & $27.00^{\mathrm{a}}$ & $192.25^{\mathrm{a}}$ \\
\hline L3: 25 ml/liter air & $14.29^{\mathrm{a}}$ & $175.84^{\mathrm{a}}$ & $28.13^{\mathrm{b}}$ & $197.75^{\mathrm{b}}$ \\
\hline L4: $30 \mathrm{ml} /$ liter air & $17.18^{\mathrm{b}}$ & $193.35^{\mathrm{b}}$ & $29.93^{c}$ & $280.50^{\mathrm{c}}$ \\
\hline NP. UJBNT taraf $5 \%$ & 2.52 & 18.83 & 1.94 & 26.33 \\
\hline
\end{tabular}

Keterangan : Angkayang diikuti oleh hurufyang tidaksama berarti berbeda sangat nyatapada UJBNT taraf 5\%. 